\title{
Early Triassic gastropods from Salt Range, Pakistan
}

\author{
AndRZeJ Kaim, Alexander Nützel, Michael Hautmann \& Hugo Bucher
}

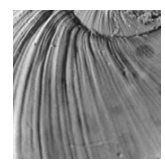

\begin{abstract}
Five gastropod species are described from the Early Triassic (Smithian, Spathian) of the Salt Range in Pakistan, which is the first detailed documentation of gastropods from this key area of the Palaeozoic-Mesozoic transition. Bellerophontoidea are represented by Warthia hisakatsui. Bellerophontoidea were widespread in the Paleozoic and had their last appearance in the early Smithian. Anisian and later reports of this group are discussed, but currently remain doubtful. Soleniscidae, a typical Late Palaeozoic caenogastropod family, are present with two new species: Strobeus batteni and S. pakistanensis. The neritimorph genus Naticopsis and the caenogastropod Coelostylina are present with one species each, provisionally treated in open nomenclature. Naticopsis? sp. shows preservation of original colour patterns, which is very rare in Early Triassic gastropods. All identified genera originated during the Paleozoic (perhaps with the exception of Coelostylina) and are thus survivors or holdovers. Warthia and Strobeus survived the end-Permian mass extinction but went extinct during the Smithian when environmental conditions deteriorated again. - Key words: Gastropoda, Pakistan, Salt Range, Early Triassic, extinction, recovery, taxonomy.
\end{abstract}

KaIM, A., NÜTZEL, A., HAUTMAnN, M. \& BUChER, H. 2013. Early Triassic gastropods from Salt Range, Pakistan. Bulletin of Geosciences 88(3), 505-516 (7 figures). Czech Geological Survey, Prague. ISSN 1214-1119. Manuscript received November 9, 2012; accepted in revised form February 8, 2013; published online March 4, 2013; issued July 3, 2013.

Andrzej Kaim, Instytut Paleobiologii PAN, ul. Twarda 51/55,00-818 Warszawa, Poland; kaim@twarda.pan.pl • Alexander Nützel, Bayerische Staatssammlung für Paläontologie und Geologie, Ludwig-Maximilians-University Munich, Department für Geo- und Umweltwissenschaften, Paläontologie und Geobiologie, Geobio-Center ${ }^{\text {LMU }}$, Richard Wagner Str. 10, 80333 München, Germany; a.nuetzel@lrz.uni-muenchen.de • Michael Hautmann \& Hugo Bucher, Paläontologisches Institut und Museum, Universität Zürich, Karl Schmid-Strasse 4, 8006 Zürich, Switzerland

The Salt Range is one of the classical regions for the study of Permian-Triassic marine sections. Ammonites are especially well studied and provide an excellent stratigraphic framework (e.g., Waagen 1895; Brühwiler et al. 2010, $2011,2012)$. The present study is the first systematic description of gastropods from the Early Triassic (Smithian/Spathian) of this area. Early Triassic gastropods from the Salt Range were mentioned or illustrated by various authors (e.g., Griesbach 1891, Waagen 1895, Bittner 1899, Schindewolf 1953, Kummel \& Teichert 1970, Nützel 2005) but were never studied in detail. The taxa were usually treated in open nomenclature and only mentioned in the text but rarely illustrated. The present gastropod collection comprises five species, indicating that regional gastropod diversity was relatively low. However, given the low total number of described Early Triassic gastropod species, the documentation of these taxa is an important step towards a better understanding of the effects of the end-Permian mass extinction and subsequent Early Triassic global changes on the recovery of Gastropoda and benthic communities. Moreover, the present material is relatively well preserved, which is unusual for Early Triassic gastropods. The good preservation facilitates a reliable ta- xonomy, which is crucial for understanding gastropod evolution at the Palaeozoic-Mesozoic transition.

\section{Geological setting}

The Salt Range provides a highly fossiliferous record of marine sediments spanning the Palaeozoic-Mesozoic transition, making this area a key locality for Permotriassic biostratigraphy and the study of the end-Permian mass extinction. A lithostratigraphic subdivision of the Early Triassic part of these sediments (Mianwali Formation; Kummel \& Teichert 1966) was proposed by Waagen (1895) and has been confirmed as regionally robust by Guex (1978). Accordingly, Lower Triassic sediments of the Salt Range can be subdivided in seven lithological units, which include in ascending order: the Kathwai Member, Lower Ceratite Limestone (LCL), Ceratite Marls (CM), Ceratite Sandstone (CS), Upper Ceratite Limestone (UCL) including the Bivalve Beds (BB), Niveaux Intermédiaires (NI) and Topmost Limestone (TL). Because of diachrony, the exact age of the boundaries of some of these units change laterally. Age assignments of the gastropod occurrences are thus discussed separately for each section. 

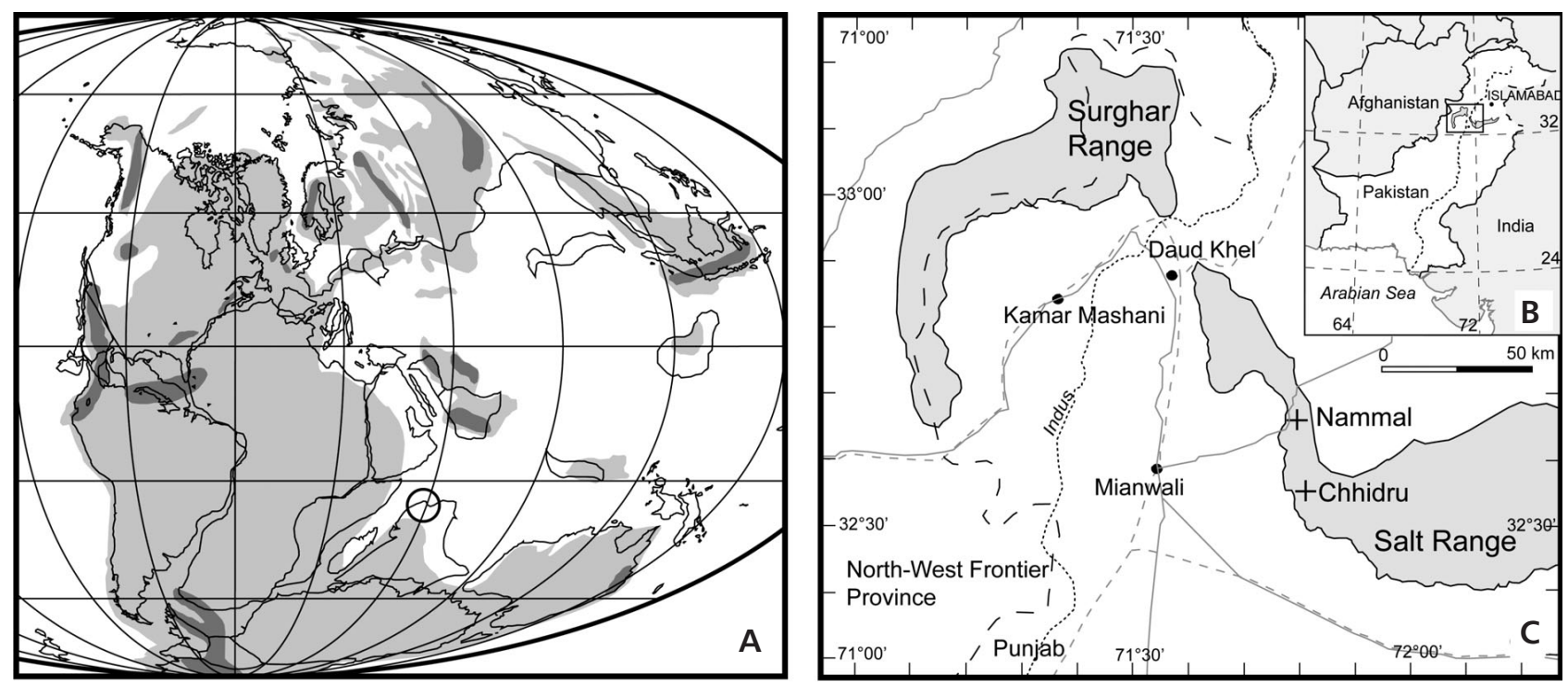

Figure 1. Locality map, showing palaeogeographic position (A), location of the working area (B) and location of sections mentioned in the text (C). Modified from Hermann et al. (2011).

The material herein described stems from two classical sections in the Salt Range (Fig. 1). The first one is Nammal gorge, which is the type locality of the Nammalian stage of Guex (1978), an interval that corresponds to the DienerianSmithian substages of the present stratigraphical nomenclature. The Lower Triassic part of the Nammal section encompass 118 meters of mixed calcareous-siliciclastic sediments of Griesbachian to Spathian age, which however, are notably condensed in the Griesbachian and include a hiatus near the base of the Spathian (Hermann et al. 2011, Wasmer et al. 2012). The Dienerian-Smithian boundary is located within the Ceratite Marls of this section (Hermann et al. 2011), and the Smithian-Spathian boundary coincides approximately with the lower boundary of the Bivalve Beds (unpublished ammonoid and conodont data). Gastropods described herein are from the LCL, CM, CS, and BB, representing an interval spanning Dienerian to the middle Spathian times.

The section at Chhidru gorge is located $c a 25 \mathrm{~km}$ south of Nammal gorge and exposes a Lower Triassic interval reaching from the Kathwai Member to the Bivalve Beds. In Chhidru, the thickness of this interval is slightly higher than in Nammal (90 m versus $72 \mathrm{~m}$ ) and has the Griesbachian-Dienerian boundary bracketed between two successive ammonoid-rich limestone beds at the transition between LCL and CM (Hermann et al. 2011). The gastropod material from this section stems exclusively from the CS, which is early Smithian in age.

\section{Material}

Gastropod samples from the Nammal section came from an interval encompassing the $\mathrm{CM}$ above the Dienerian-
Smithian boundary, CS, and $\mathrm{BB}$, corresponding to a Smithian-middle Spathian time interval. Samples from Chhidru are exclusively from the CS (early Smithian). Figure 2 shows the stratigraphic position of the samples.

Some of the gastropods studied herein are from the Palaeontological collection of the University of Tübingen. They lack detailed locality and stratigraphic information. The labels give the information "Upper Ceratite Beds, Bellerophon Bed, Mittialiwani near Chideru" which probably refers to the Mittiwali Member of the Mianwali Formation (see Kummel \& Teichert 1970). The small Coelostylina specimens reported herein come from a single small rock of grayish limestone which yields numerous tiny specimens of these gastropods.

\section{Systematic palaeontology}

Class Gastropoda Cuvier, 1797

Order Amphigastropoda Simroth, 1906

Superfamily Bellerophontoidea McCoy, 1852

Family Euphemitidae Knight, 1956

\section{Genus Warthia Waagen, 1880}

Type species. - Warthia brevisunuata Waagen, 1880, subsequent designation by de Koninck (1882); Middle Permian, Salt Range, Pakistan.

\section{Warthia hisakatsui Murata, 1981}

Figure 3A-H

1891 Bellerophon sp.; Griesbach 1891, p. 146. 

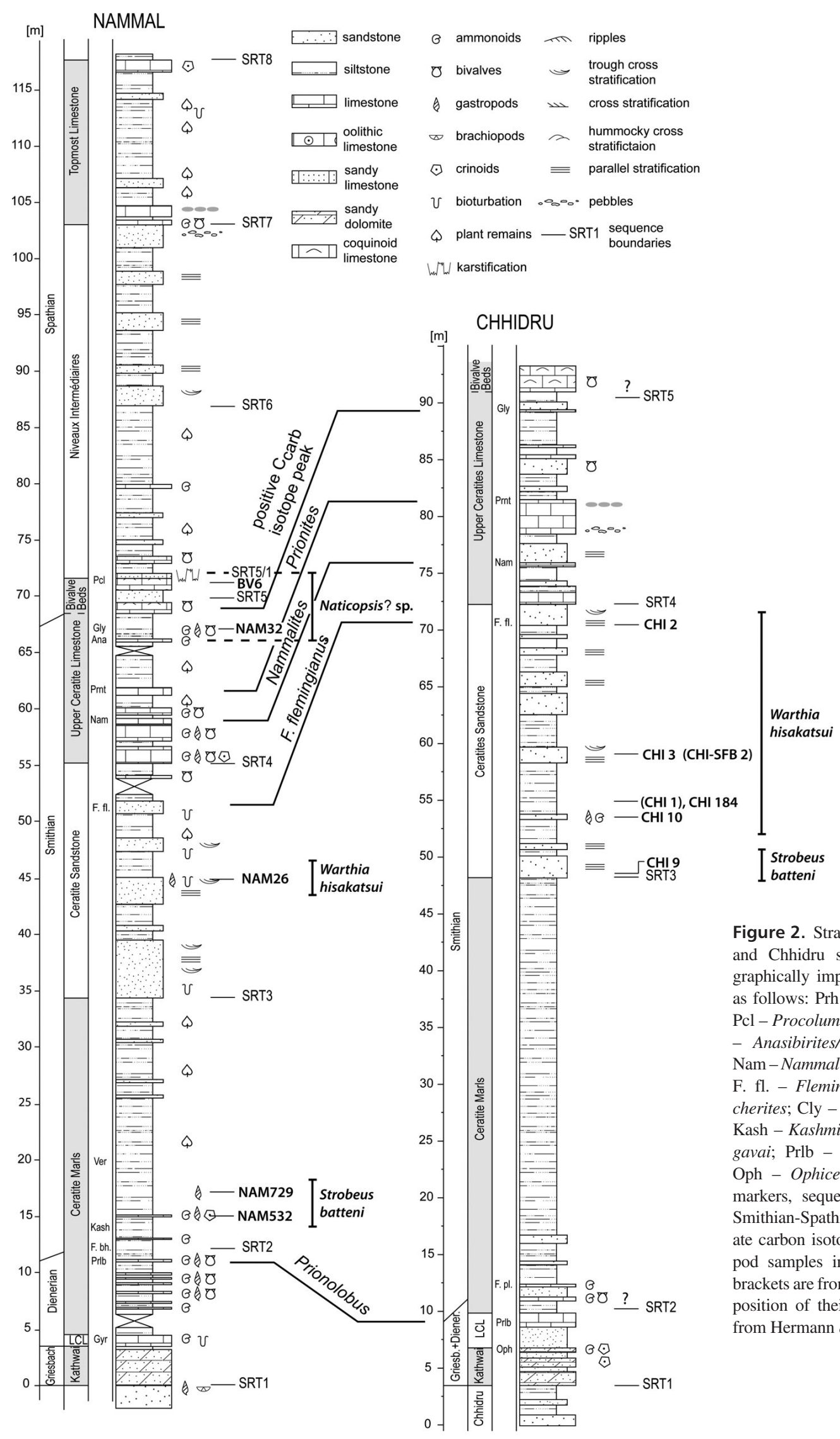

Figure 2. Stratigraphic column of the Nammal and Chhidru sections. Occurrences of stratigraphically important ammonoids are indicated as follows: Prh - Prohungarites; $\operatorname{Tr}$ - Tirolites; Pcl - Procolumbites; Gly - Glyptophiceras; Ana - Anasibirites/Wasatchites; Prnt - Prionites; Nam-Nammalites; F. pl. - Flemingites planatus; F. fl. - Flemingites flemingianus, Ver - Vercherites; Cly - Clypeoceras; Par - Paranorites; Kash - Kashmirites; F. bh. - Flemingites bhargavai; Prlb - Prionolobus; Gyr - Gyronites; Oph - Ophiceras. As additional stratigraphic markers, sequence boundaries (SRT) and the Smithian-Spathian positive $\delta^{13} \mathrm{C}$ peak of carbonate carbon isotope record are indicated. Gastropod samples in bold. Samples with labels in brackets are from the float and are indicated at the position of their oldest possible age. Modified from Hermann et al. (2011). 
1895 Stachella; Waagen 1895, p. 3.

1899 Bellerophon cf. vaceki; Bittner 1899a, p. 9, pl. 1, fig. 15.

1953 Stachella; Schindewolf, 1953, p. 160.

1981 Warthia hisakatsui sp. nov.; Murata, 1981, p. 126, pl. 12, figs 1-3.

Material. - Two specimens extracted from rock matrix (PIMUZ SR-18 and 19) and numerous specimens in rock samples forming bellerophontid coquina. 40 specimens from Chhidru (CHI 1, CHI 2, CHI 3, CHI 10, CHI 26, CHI 184, CHI-SFB 2) and 5 from Nammal (Nam 26), Salt Range Pakistan. Ceratite Sandstone, early Smithian, Early Triassic.

$\begin{array}{lrrr}\begin{array}{l}\text { Measurements. }- \\ \text { Specimen number }\end{array} & \begin{array}{r}\text { Length } \\ (\mathrm{mm})\end{array} & \begin{array}{r}\text { Width } \\ (\mathrm{mm})\end{array} & \begin{array}{r}\text { Thickness } \\ (\mathrm{mm})\end{array} \\ \text { PIMUZ SR-18 } & 18.1 & 18.0 & 14.0 \\ \text { PIMUZ SR-19 } & 23.8 & 22.2 & 19.4\end{array}$

Description. - Shell globular, slightly longer than wide; no ornamentation; slit short and broad at a base of U-shaped sinus; selenizone weakly depressed; umbilicus absent.

Discussion. - Warthia hisakatsui was described by Murata (1981) based on Griesbachian material from the Guryul Ravine in Kashmir. The specimens illustrated by Murata (1981, pl. 12, figs 1-3) are moderately well preserved and display general Warthia-like morphology. Murata (1981, p. 127) considers "long curved outer lip" as a distinctive character of his new species. We are not sure what Murata (1981) meant by this character though we think that the curved posteriorly lateral parts of the lip visible on Murata's (1981) pl. 12, fig. 2a are probably what he intended to be the diagnostic character. Having not examined the actual type material housed at the Geological Survey of India in Calcutta, we are not convinced whether this is a character of significance or diagenetic distortion. All in all we could not confirm this character in any of the specimens we examined from Pakistan and we could not also observe it in all the other specimens of W. hisakatsui illustrated by Murata (1981). Another Triassic species of Warthia has been described by Kaim (2009) from Primorye, Russia based on specimens collected from different horizons corresponding to Griesbachian, Dienerian, and Smithian respectively. W. zakharovi Kaim, 2009 is very similar to W. hisakatsui in all aspects but has a smaller average size and is slightly more convolute shell (compare Fig. 3A-H and 3I-L). It also does not possess the "long curved outer lip" characteristic for W. hisakatsui as diagnosed by $\mathrm{Mu}-$ rata (1981). We remain uncertain whether W. hisakatsui and $W$. zakharovi are synonyms pending the examination of the type series of the former. Provisionally, we preserve the name W. zakharovi for Triassic Warthia from Russian Pacific Coast (see summary in Kaim \& Nützel 2011), whereas the name W. hisakatsui is used for Triassic Warthia from Himalaya and Pakistan though the records of Griesbach (1891) and Bittner (1899) from Uttarkhand, India remain uncertain. The reports of Waagen (1895) and Schindewolf (1953), both from Salt Range, are most likely conspecific with the material studied herein, because they were collected from the same geographic region and the same lithostratigraphic unit (Ceratite Sandstone). Neither Waagen (1895) nor Schindewolf (1953), however, described or illustrated their specimens. Both of them identified these specimens as Stachella, an allegedly asymmetric genus of bellerophontids. Yochelson \& Hongfu (1985) addressed the problem of Stachella stating in conclusion that the specimens identified as Stachella are most likely diagenetically distorted and poorly preserved representatives of Warthia. We failed to locate any bellerophontids in the Schindewolf's (1953) collection housed at the University of Tübingen and consider them as lost.

Warthia vaceki (Bittner, 1899) from Europe is clearly different from any of the Asiatic species due to the presence of a pseudoumbilicus (Kaim \& Nützel 2011). Warthia borealis (Spath, 1930) is a poorly illustrated species and therefore it is difficult to assess whether it is senior synonym for W. hisakatsui or W. zakharovi (Kaim \& Nützel 2011).

Order Neritimorpha Koken, 1896

Superfamily Neritoidea Rafinesque, 1815

Family Naticopsidae Waagen, 1880

\section{Genus Naticopsis M'Coy, 1844}

Type species. - Naticopsis phillipsii M'Coy, 1844 from the Lower Carboniferous of Ireland.

Naticopsis? sp.

Figures 4, 5

1953 Naticopsis; Schindewolf 1953, p. 160.

Material. - Two specimens (PIMUZ SR 01 and 02) from sample Nam 32 (Nammal, upper part of Ceratite Limestone, Glyptophiceras sinuatus Beds, latest Smithian) and thirteen specimens (PIMUZ SR 03-15) from samples Bv 6 (Nammal, Bivalve Beds, Early Spathian). All specimens from Salt Range Pakistan, Early Triassic.

Measurements. - PIMUZ SR 04 (Figs 4A-C, 5C, D, H): height $16.1 \mathrm{~mm}$, width $20 \mathrm{~mm}$.

Description. - Shell globose with rounded whorls embracing most of preceding whorls; suture weakly incised; 

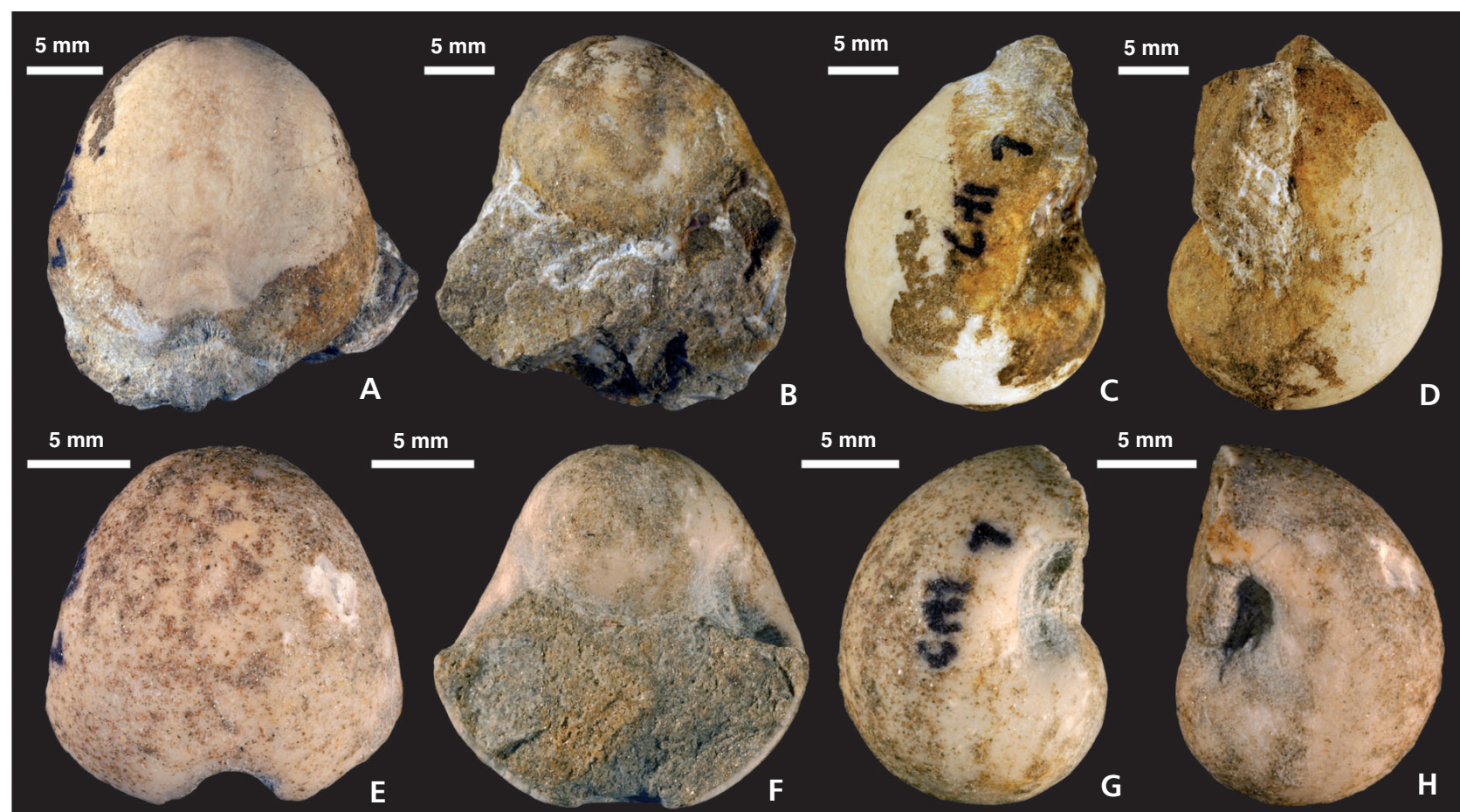

$5 \mathrm{~mm}$
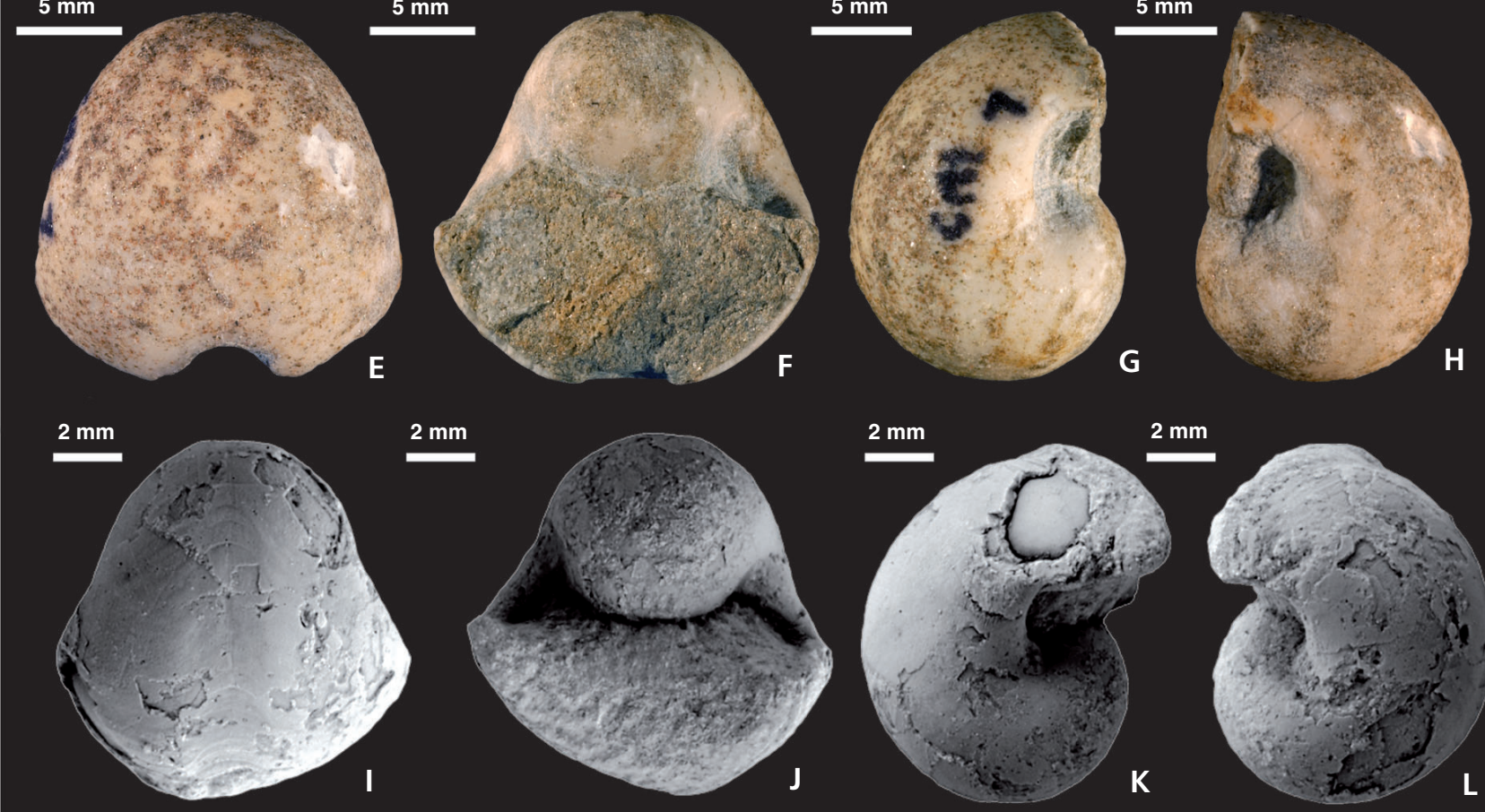

Figure 3. Early Triassic euphemitid bellerophontids Warthia hisakatsui Murata, 1981 and Warthia zakharovi Kaim, 2009. • A-H - W. hisakatsui from sample CHI-1, Chhidru, Salt Range, Pakistan. Ceratite Sandstone, early Smithian. A-D - PIMUZ SR-19; A - ventral view, B - dorsal view, C - right lateral view, D - left lateral view. E-H - PIMUZ SR-18; E - ventral view, F - dorsal view, G - right lateral view, H - left lateral view. $\bullet$ I-L - W. zakharovi Kaim, 2009, holotype NSM PM23322 from sample AB 1016, Abrek, Primorye, Far East Russia. Dienerian.

apex slightly flattened; growth lines prosocline. Aperture and juvenile whorls are not preserved in the accessible specimens. Some shells display colour pattern expressed by rusty spots distributed over the entire shell surface though not entirely preserved in all specimens at hand.

Discussion. - The shells of naticopsid neritimorphs are simple in morphology and display relatively few taxonomically important characters. The naticopsid from Pakistan does not have the protoconch and aperture preserved and therefore we decided to leave it in open nomenclature. It resembles the Carboniferous type species of Naticopsis (see Knight 1941) in the low-spired general shape with a slightly elevated spire, the simple growth lines and in having a smooth shell (see also Nützel et al. 2007). Among the Late Triassic Neritimorpha, genera such as Dicosmos or Neritaria are similar (e.g., Bandel 2007) and additional information is needed for a safe taxonomic assignment of the present species (aperture, inner whorls resorbed or not, larval shell etc.). The present material resembles Naticopsis sp. described by Kaim et al. (2010) from the Griesbachian of South China. It also resembles Naticopsis utahensis Batten \& Stokes, 1986 from the Lower Triassic (Smithian) Sindbad Limestone (Utah, USA) but has a somewhat flatter spire. The present material may also be attributed to Abrekopsis depressispirus (Batten \& Stokes, 1986) known from Sinbad Limestone (Batten \& Stokes 1986) and Primorye (Kaim 2009). However, without juvenile whorls preserved this supposition cannot be 


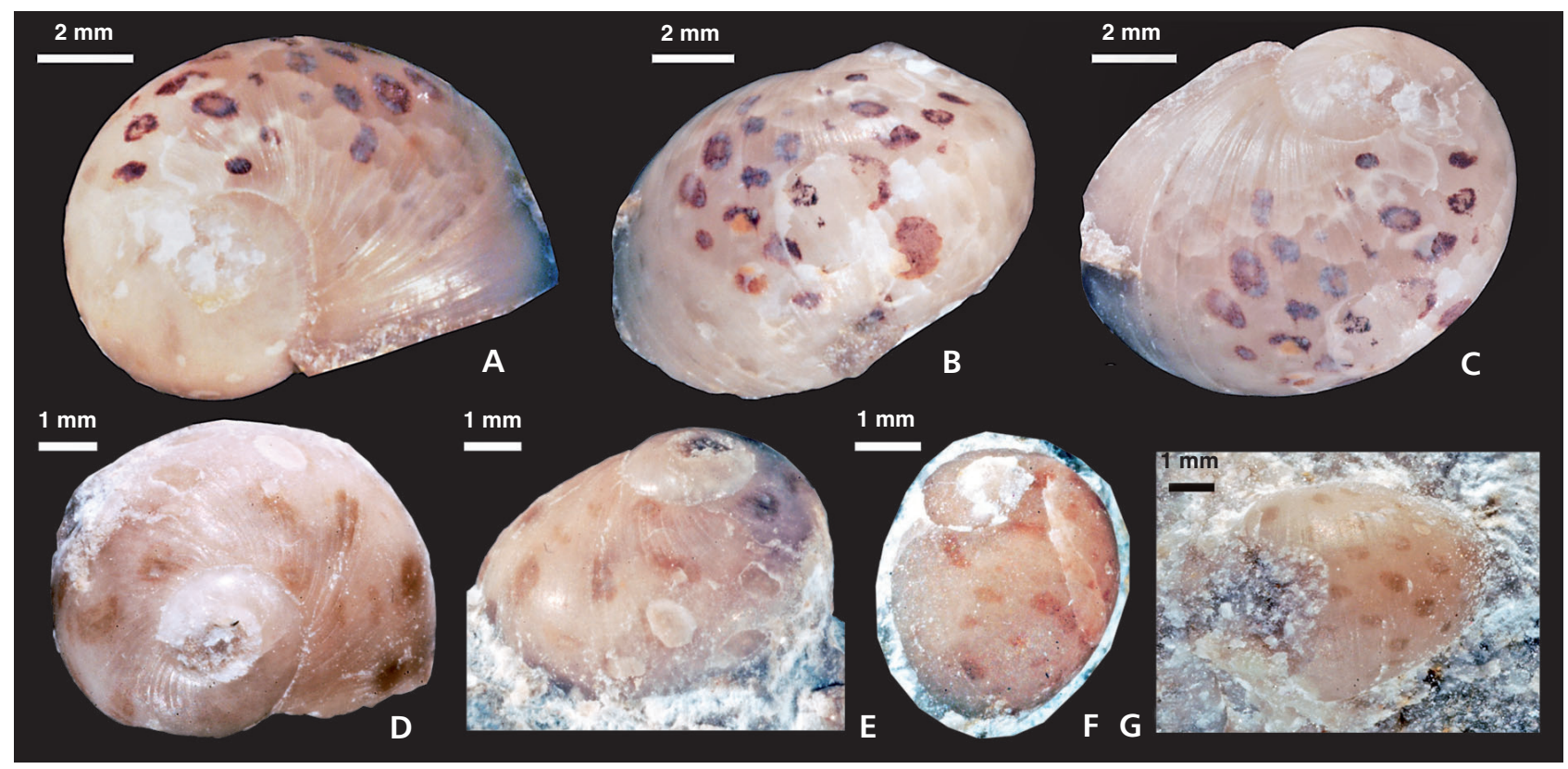

Figure 4. Early Triassic naticopsid gastropod Naticopsis? sp. from Salt Range, Pakistan displaying colour pattern. • A-C - PIMUZ SR-04 from Early Spathian Bivalve Beds (sample Bv 6); A - apical view, B - lateral view, C - latero-apical view. $\bullet$ D, E - PIMUZ SR-07 from Early Spathian Bivalve Beds (sample Bv 6); D - apical view, E - latero-apical view. $\bullet$ F, G - sample Nam 32, Nammal, upper part of Ceratite Limestone, Glyptophiceras sinuatus Beds, latest Smithian; F - PIMUZ SR-01 in latero-apical view, G - PIMUZ SR-02 in lateral view.

substantiated. The colour pattern revealed by shells Naticopsis sp. from Pakistan is a common pattern known from some Triassic, e.g. Fedaiella neritacea (Münster, 1841), and other, e.g., Devonian Paffrathopsis harpula (Sowerby, 1827) neritimorphs and even Recent naticids (for review see Tichy 1980).

Order Caenogastropoda Cox, 1960

Superfamily Acteoninoidea Cossmann, 1895

Family Soleniscidae Knight, 1931

\section{Genus Strobeus de Koninck, 1881}

Type species. - Strobeus ventricosus de Koninck, 1881 from Carboniferous of Belgium.

\section{Strobeus batteni sp. nov.}

Figure 6C-E, I

1986 Strobeus cf. paludinaeformis (Hall); Batten \& Stokes, p. 29, figs 49-51.

2005 Soleniscus sp. or Strobeus sp.; Nützel, p. 441, fig. 7, middle and right.

2005 Soleniscus?; Wheeley \& Twitchett, p. 40, fig. 2L, M.

Types. - Holotype PIMUZ.SR-16.

Type locality. - Chhidru, Salt Range, Pakistan.
Type horizon. - Lowermost bed (CHI 9) of Ceratite Sandstone, early Smithian, Early Triassic.

\section{Etymology. - After Roger L. Batten.}

Material. - Holotype (PIMUZ.SR-16) and two additional specimens from Nammal, one from sample NAM532 (PIMUZ.SR-17) and the other from sample NAM729 (PIMUZ.SR-45).

Measurements. -

Specimen number Height Width Height/width Aperture $\begin{array}{lllll} & (\mathrm{mm}) & (\mathrm{mm}) & \text { ratio }(\mathrm{mm}) & (\mathrm{mm})\end{array}$ (holotype)

$\begin{array}{lllll}\text { PIMUZ.SR-17 } & 30.8 & 17.1 & 1.80 & 19.4\end{array}$

Diagnosis. - A species of Strobeus with an even rate of shell expansion, aperture with an anterior notch and small but deep umbilicus.

Description. - Protoconch unknown. Shell moderately high-spired with 5 whorls preserved in the holotype. Suture moderately impressed, lateral flanks evenly convex with no shoulder or ramp. No clear demarcation between lateral flank and the base. Shell surface smooth. Growth lines slightly prosocyrt, almost orthocline. Aperture slit-like, oblique, poorly preserved but with clear anterior notch and a siphonal fold (Fig. 6C, I). Outer lip not preserved. Inner lip 


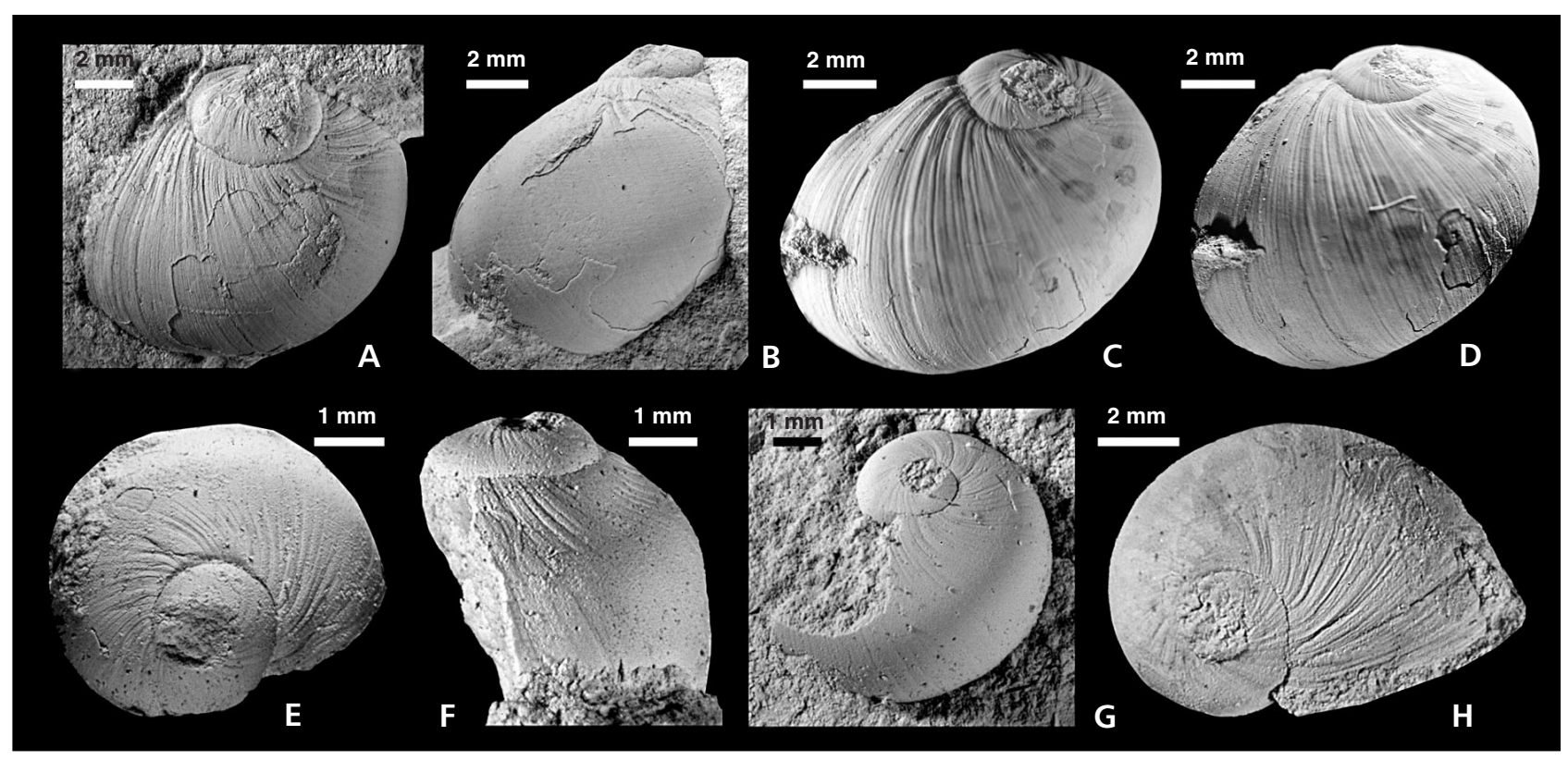

Figure 5. Early Triassic naticopsid gastropod Naticopsis sp. from the Early Spathian Bivalve Beds (sample Bv 6), Salt Range, Pakistan. • A, B - PIMUZ SR-03; A - latero-apical view, B - lateral view. • C, D, H - PIMUZ SR-04; C - latero-apical view, D - lateral view, H - apical view. • E, F - PIMUZ SR-07; E - apical view, F - lateral view. $\bullet \mathrm{G}$ - PIMUZ SR-06, latero-apical view.

not thickened in the parietal part, slightly bulged in the abapical portion of the columellar part forming small but deep pseudumbilicus. Regrettably this part seems to be slightly distorted on both available specimens and the imperfect preservation precludes further observations.

Remarks. - Strobeus batteni differs from S. pakistanensis (see below) in having an even rate of the shell expansion. The last whorl covers aproximately $71 \%$ of the entire height in S. pakistanesis while only $65 \%$ in S. batteni. Moreover, the whorls of $S$. batteni are less convex and the suture is less incised. It seems also that $S$. pakistanensis lacks the anterior notch which is present in S. batteni. The difference between S. batteni and S. shigetai Kaim, 2009 from Early Triassic of Primorye (Kaim 2009) remains uncertain as the latter is based on juvenile specimens, however, a new unpublished adult specimen from early Smithian Tri Kamnia Cape locality (Primorye) suggest that the gross morphology of S. shigetai is more similar to the one of S. pakistanensis. S. batteni differs from Strobeus paludinaeformis (Hall, 1858) from Carboniferous of Iowa (Hall 1858) in being less elongated and having smaller number of whorls. Batten \& Stokes (1985) classified the Strobeus shells from Upper Smithian Sinbad Formation in Utah, USA as Strobeus cf. paludinaeformis (Hall, 1858), stating that the species seems to be quite morphologically diverse. We include tentatively this form to our S. batteni pending further investigations of the form from the Sinbad Formation.

Strobeus batteni is a typical representative of the family Soleniscidae and the genus Strobeus which is diverse in the
Late Palaeozoic (e.g., Knight 1941, Harper 1981, Nützel et al. 2000, Kues \& Batten 2002). It shares the globular fusiform shape, the smooth shell and the siphonal fold with the Early Carboniferous type species from Belgium (Knight 1941) and with other Palaeozoic species species assigned to this genus. Soleniscus is generally similar but more slender.

Occurrences. - Apart from Salt Range this species seems to be present in Sinbad Formation (Smithian) of Utah (Batten \& Stokes 1986, Nützel 2005) and we suppose that the poorly preserved Strobeus from Griesbachian of Oman (Wheeley \& Twitchett 2005) may also belong here.

\section{Strobeus pakistanensis sp. nov.}

Figure 6A, B, F-H, J-L

2005 Strobeus sp.; Nützel, p. 441, fig. 7, left.

Types. - Holotype GPIT/GA/05034, paratypes (GPIT/GA/05035, 36).

Type locality. - Mittialiwani near Chhidru, Salt Range, Pakistan.

Type horizon. - Upper Ceratite Beds, Bellerophon Bed (probably Mittiwali Member of Mianwali Formation), ?early Smithian, Early Triassic.

Etymology. - After Pakistan, the country of origin. 
Material. - Holotype (GPIT/GA/05034), adult or adolescent shell, two more (GPIT/GA/05035, 36) adult or adolescent shells (paratypes) and probably single juvenile specimen (GPIT/GA/05037); all from Mittialiwani near Chhidru, Salt Range, Pakistan.

$\begin{array}{lrrrr}\begin{array}{l}\text { Measurements. - } \\ \text { Specimen number }\end{array} & \begin{array}{r}\text { Height } \\ (\mathrm{mm})\end{array} & \begin{array}{r}\text { Width } \\ (\mathrm{mm})\end{array} & \begin{array}{c}\text { Height/width } \\ \text { ratio (mm) }\end{array} & \begin{array}{r}\text { Aperture } \\ (\mathrm{mm})\end{array} \\ \begin{array}{l}\text { GPIT/GA/05034 } \\ \text { (holotype) }\end{array} & 18.8 & 11.3 & 1.66 & 12.5 \\ \begin{array}{l}\text { GPIT/GA/05035 } \\ \text { (paratype) }\end{array} & 14.7 & 10.7 & 1.37 & 9.1 \\ \begin{array}{l}\text { GPIT/GA/05036 } \\ \text { (paratype) }\end{array} & 14.0 & 10.2 & 1.37 & - \\ \begin{array}{l}\text { GPIT/GA/05037 } \\ \text { (juvenile) }\end{array} & 3.29 & 2.82 & 1.16 & -\end{array}$

Diagnosis. - Strobeus with smooth juvenile whorls, simple suture, increasing expansion rate, convex whorls and complete peristome.

Description. - First whorl corroded. Remaining protoconch whorls and juvenile whorls smooth. Transition from protoconch to teleoconch unknown. First three to four whorls blunt, low-spired with much larger apical angle than subsequent whorls. Shell moderately high-spired with 6 whorls preserved in the largest specimen (holotype). Sutures moderately impressed, flanks evenly convex with no shoulder or ramp. Adult/adolescent whorls with increasing expansion rate. No clear demarcation between lateral flank and the base. Shell surface smooth. Growth lines not discernible. Outer lip seems to be opistocyrt in one of the paratypes (GPIT/GA/05035) though it might be preservational feature. Inner lip not thickened and complete without additional elaborations.

Remarks. - S. pakistanensis differs from S. shigetai Kaim, 2009 from Early Triassic of Primorye (Kaim 2009) in much lower height/width ratio of the juvenile shell (1.16) which in S. shigetai is 1.42 . Moreover, $S$. shigetai is ornamented with faint axial lirae and its suture is covered by thin layer of the following whorl; both features absent in S. pakistanensis. S. pakistanensis differs from S. batteni in having a continuous peristome (no anterior notch), increasing expansion rate and much more convex whorls. According to its egg-shape and the smooth whorls, Strobeus pakistanensis is a typical soleniscid and can be attributed to Strobeus as defined by Harper (1981) and Nützel et al. (2000) although a columellar fold seems to be absent. However, Harper (1981) noted that a fold is only variably developed in Strobeus. The protoconch of Strobeus pakistanensis is smooth as is also the case in Late Palaeozoic Soleniscidae (Nützel et al. 2000, Nützel \& Pan 2005).
Occurrence. - S. pakistanensis is known so far exclusively from the early Smithian of Salt Range.

Superfamily Zygopleuroidea Wenz, 1938

Family Coelostylinidae Cossmann, 1909

\section{Genus Coelostylina Kittl, 1894}

Type species. - Melania conica Münster, 1841 from Carnian (Upper Triassic) St. Cassian Formation of northern Italy.

\section{Coelostylina sp.}

Figure 7

Material. - Numerous juvenile specimens in a single rock sample (Fig. 7E). Several extracted specimens (GPIT/GA/05038-05043) consist of protoconch and half of the teleoconch whorl. The rock sample most likely is derived from Upper Ceratite Beds, Bellerophon Bed (probably Mittiwali Member of Mianwali Formation), ?early Smithian, Early Triassic.

Measurements. - Specimen GPIT/GA/5042: Height $0.76 \mathrm{~mm}$, width $0.58 \mathrm{~mm}$.

Description. - Embryonic whorl not preserved. Protoconch high-spired, consisting of at least three whorls. Growth lines of the protoconch opisthocyrt while in early teleoconch sinusoidal. No clear demarcation between protoconch and teleoconch though intermediate zone well visible. Late protoconch and early teleoconch whorls display rows of small pits which most likely are remnants of periostracal hairs. No other ornamentation both on protoconch and teleoconch. Aperture not preserved.

Discussion. - These juvenile shells are similar to Coelostylina sp. from Early Triassic of Primorye (Kaim 2009). However, both forms are not well preserved and therefore remained in the open nomenclature.

\section{Discussion and conclusions}

The present Early Triassic gastropods of the Salt Range seem to represent genera which are Palaeozoic survivors or holdovers. The bellerophontoid Warthia is known form the Late Paleozoic and the Early Triassic. The Early Triassic occurrences of this genus were summarized by Kaim \& Nuitzel (2011). Generally, Bellerophontoidea cross the Paleozoic-Mesozoic boundary with several genera (see Kaim \& Nützel 2011). In the Early Triassic, they are globally distributed and locally abundant but became extinct during the Smithian (Kaim \& Nützel 2011) as part of a 

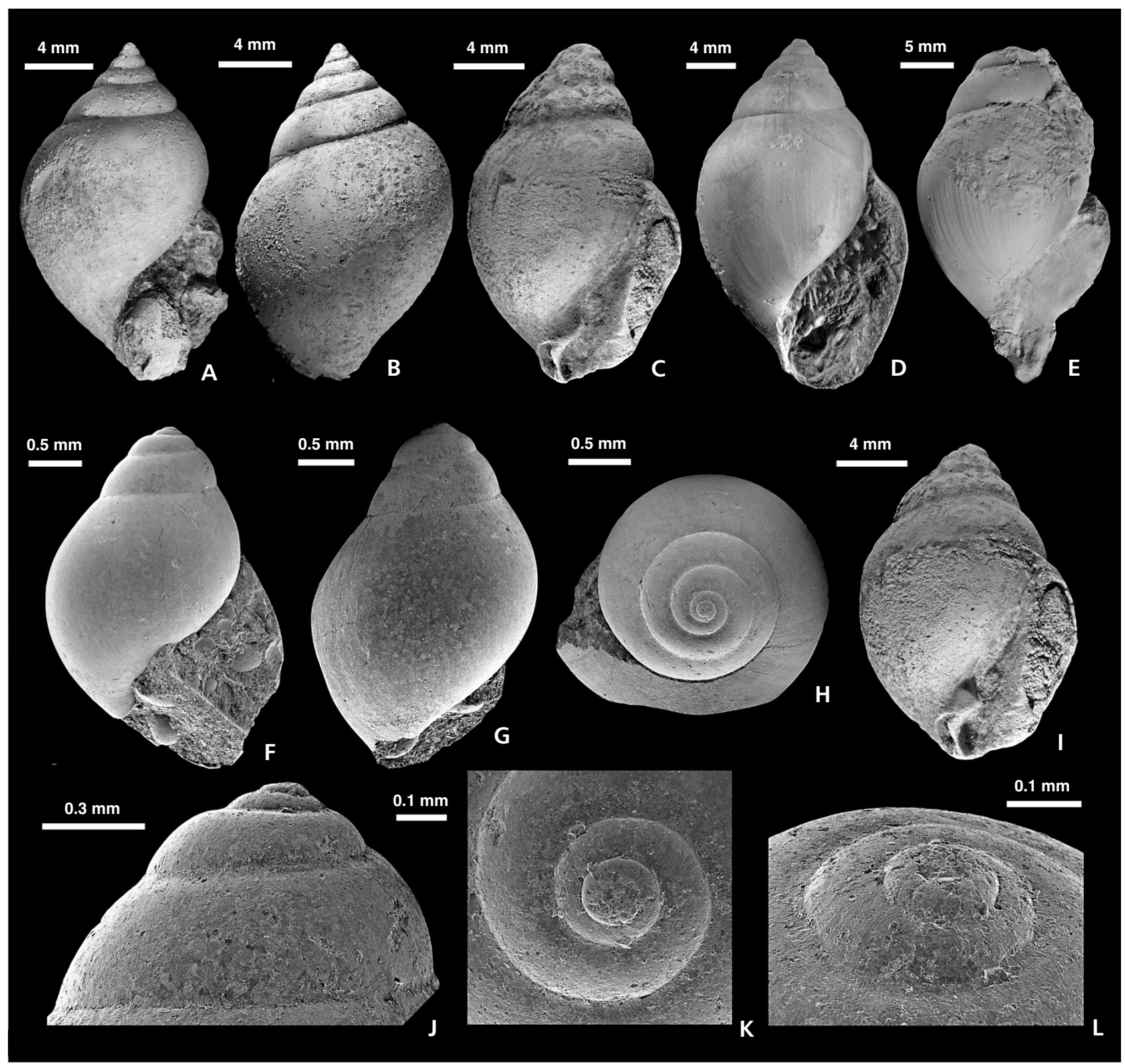

Figure 6. Early Triassic soleniscid gastropods Strobeus pakistanensis sp. nov. and Strobeus batteni sp. nov. from Salt Range, Pakistan. • A, B, F-H, J-LS. pakistanensis from Mittialiwani near Chhidru, Salt Range, Pakistan. Upper Ceratite Beds, Bellerophon Bed (probably Mittiwali Member of Mianwali Formation), ?early Smithian, Early Triassic. A, B - holotype GPIT/GA/05034; A - apertural view, B - lateral view. F-H, J-L - juvenile specimen GPIT/GA/05037; F - apertural view, G - lateral view, $\mathrm{H}$ - apical view, J - close-up of the apex in lateral view, $\mathrm{K}$ - close-up of the apex in apical view, $\mathrm{L}$ - close-up of the apex in latero-apical view. $\bullet$ C-E, I - S. batteni. C, I - holotype PIMUZ SR-16 from sample CHI 9, Chhidru, lowermost bed of Ceratite Sandstone, early Smithian; $\mathrm{C}$ - apertural view, I - aperturo-umbilical view displaying posteriormost aperture elaborations. $\bullet$ D - PIMUZ SR 45 from sample Nam 729, Nammal, Ceratite Marls 2-10, ?Smithian in apertural view. • E - PIMUZ SR 17 from sample Nam 532, Nammal, ?Smithian in apertural view.

larger Smithian extinction event (Romano et al. 2012). There are no credible records of Bellerophontoidea from the Spathian or later (Kaim \& Nützel 2011). The dubious Anisian record of Dicellonema dicellonemata Yü \& Wang in Yü (1975) from Tulong (Nyalam County, Tibet) is considered as unlikely by Kaim \& Nützel (2011). This species is from the middle part of the Tulong Formation that according to Yü (1975) belongs to the Anisian (Middle Triassic).
However, Garzanti et al. (1998) noted that Middle Triassic deposits are restricted to the uppermost part at the type locality. Thus, the middle part including the occurrence of Dicellonema dicellonemata is probably Early Triassic Smithian or Spathian (see also Brühwiller et al. 2009, 2010). All other well known Anisian gastropod faunas are clearly devoid of Bellerophontoidea, e.g., the Muschelkalk (e.g., Schmidt 1928, 1938) or from Quingyan (Guizhou, 


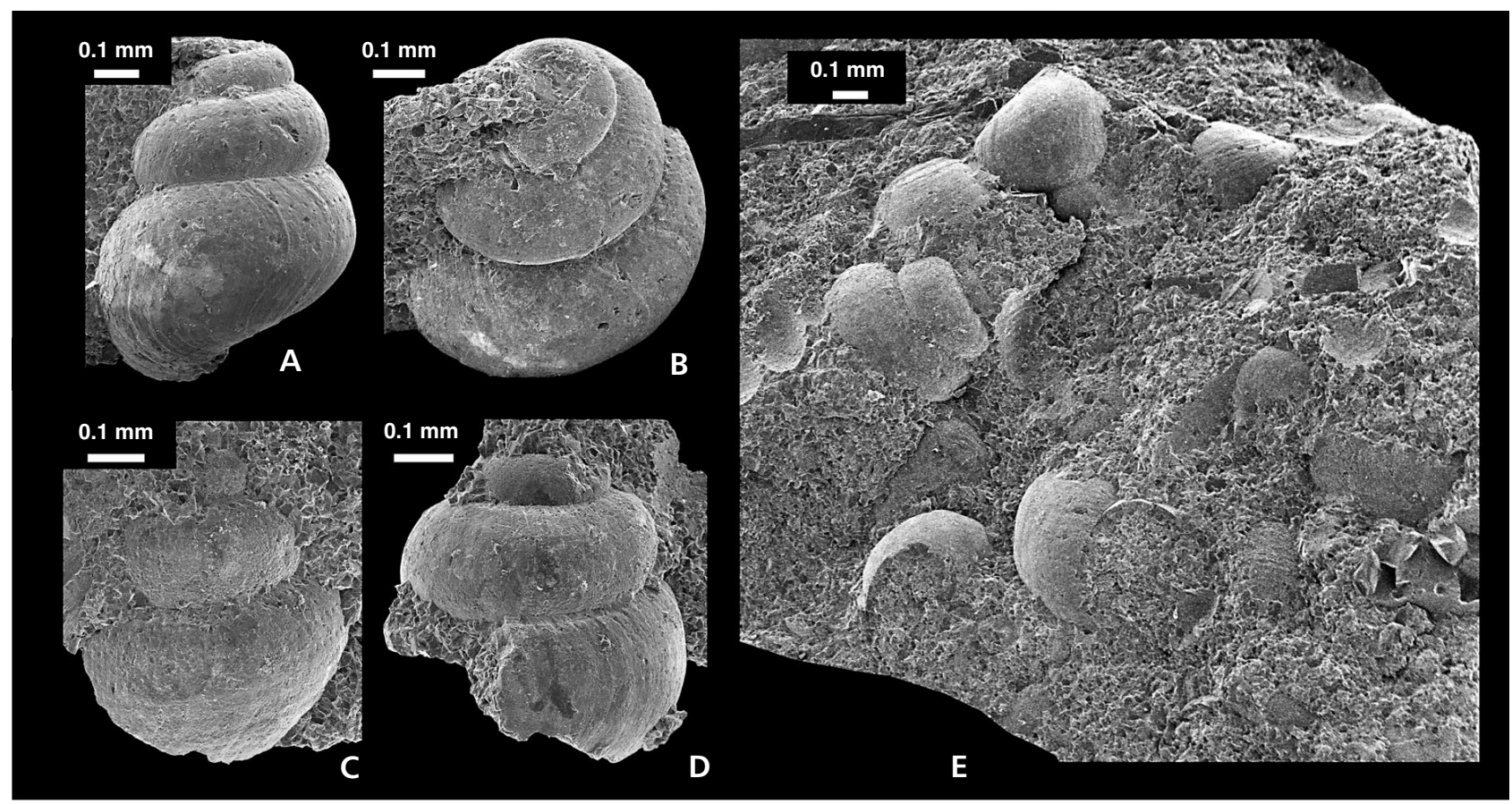

Figure 7. Early Triassic gastropod Coelostylina sp. from Mittialiwani near Chhidru, Salt Range, Pakistan. Upper Ceratite Beds, Bellerophon Bed (probably Mittiwali Member of Mianwali Formation), ?early Smithian, Early Triassic. • A, B - juvenile GPIT/GA/05038; A - lateral views, B - latero-apical view. $\bullet$ C - GPIT/GA/5041, lateral view showing faint spiral ornamentation. $\bullet$ D - GPIT/GA/05042. $\bullet$ - GPIT/GA/05039, rock sample with numerous juvenile specimens.

SW China) (Stiller 2001) although bellerophontoids are easily recognized by their bilateral symmetrical shape even if the preservation is poor. As mentioned, there is also no confirmed Spathian or younger record, so far.

The neritimorph Naticopis is extremely diverse in the Late Palaeozoic (e.g., Branson 1948, Yochelson \& Saunders 1967, Nützel et al. 2007, Nützel \& Nakazawa 2012). This genus or other similar genera are also abundant and widespread in the Triassic (e.g., Bandel 2007) including some Early Triassic species for instance in the Sinbad Limestone (Batten \& Stokes 1986, Nützel 2005, Nützel \& Schulbert 2005). However, smooth neritimorphs are difficult to identify. Only if the shape of the aperture, of early ontogenetic shell and the status of the inner whorls (resorbed/not resorbed) are known can a sound generic assignment be proposed; open nomenclature is commonly used if these characters are unknown (Kaim et al. 2010). Thus, although smooth neritimorphs are common in Early Triassic gastropod faunas, the evolutionary pathways of Neritimorpha are difficult to trace across the Paleozoic/Mesozoic boundary. The colour preservation of the present neritimorph species is remarkable. The only other case of colour preservation in an Early Triassic gastropod we know of is that of Naticopsis arctica Spath, 1930 from Greenland. Generally, colour preservation is relatively frequent in Neritimorpha and is obviously facilitated by a thin outer calcitic layer that is typical for this group.
Soleniscidae are diverse and widespread in the Late Palaeozoic. The presence of Strobeus or Solenisus in the Early Triassic was reported by Batten \& Stokes (1986), Nützel (2005), Wheeley \& Twitchett (2005) and Kaim (2009). So far no later Triassic or younger species has been assigned to Soleniscus or to the similar genus Strobeus. Possible phylogenetic relationships of Soleniscidae to younger smooth shelled caenogastropods are not well understood.

The smooth shelled caenogastropod genus Coelostylina is very diverse in the Triassic. Currently 48 Triassic species are assigned to Coelostylina, among them a few Early Triassic ones. There are also Permian representatives of this genus (e.g., Dietz 1911, Hollingworth \& Pettigrew 1988). In addition, some species which have been assigned to the smooth-shelled genus Omphaloptycha resemble also Coelostylina. Omphaloptycha is highly diverse in the Triassic and several Permian species have been assigned to this genus (Batten 1985, Nützel \& Nakazawa 2012). These commonly small, smooth caenogastropods display only a very low number of characters and therefore taxonomic assignments and evolutionary scenarios are problematic.

It is worth of note that none of the taxa in the newly collected material co-occur with each other in the Salt Range sections. The oldest is Strobeus batteni, which occurs in the Ceratite Marls and lowermost Ceratite Sandstone (early Smithian). Higher up, there are numerous occurrences of Warthia hisakatsui in the middle and upper parts of Ceratite Sandstone while Naticopsis? sp. is known from 
Upper Ceratite Limestone and Bivalve Beds (upper Smithian and lowermost Spathian, respectively). This pattern shows that bed-by-bed collecting of Early Triassic fossils is essential for understanding the dynamics of their recovery.

\section{Acknowledgements}

AK research was supported by Alexander von Humboldt Foundation return fellowship. AN acknowledges support by the Deutsche Forschungsgemeinschaft (Grant NU 96/6-1, 6-2). The study of the Early Triassic record in the Salt Range was supported by the Swiss National Science Foundation (project SNF 135446 to HB). Jiř́ Frýda (Praha, Czech Republic) and an anonymous referee are acknowledged for peer reviews.

\section{References}

BANDEL, K. 2007. Description and classification of Late Triassic Neritimorpha (Gastropoda, Mollusca) from St. Cassian Formation, Italian Alps. Bulletin of Geosciences 82(3), 215-274. DOI 10.3140/bull.geosci.2007.03.215

Batten, R.L. 1985. Gastropods and chitons from Perak, Malaysia. Part 3: The murchisoniids, cerithiids, loxonematids, and subulitids. American Museum Novitates 2829, 1-40.

Batten, R.L. \& Stokes, W.M. 1986. Early Triassic gastropods from Sinbad Member of the Moenkopi Formation, San Rafael Swell, Utah. American Museum Novitates 2864, 1-33.

Bittner, A. 1899. Himalayan Fossils. Vol. III., Part 2. Trias Brachiopoda and Lamellibranchiata. Palaeontologia Indica 15(3), 1-76.

Branson, C.C. 1948. Bibliographic index of Permian Invertebrates. Geological Society of America Memoir 26, 1-1049.

Brühwiler, T., Bucher, H., Brayard, A. \& Goudemand, N. 2010. High-resolution biochronology and diversity dynamics of the Early Triassic ammonoid recovery: the Smithian faunas of the Northern Indian Margin. Palaeogeography, Palaeoclimatology, Palaeoecology 297, 491-501.

DOI 10.1016/j.palaeo.2010.09.001

Brühwiler, T., Bucher, H. \& Goudemand, N. 2010. Smithian (Early Triassic) ammonoids from Tulong, South Tibet. Geobios 43, 403-431. DOI 10.1016/j.geobios.2009.12.004

BrüHwiler, T., Bucher, H., RoOH, G., YAseen, A. \& Rehman, K. 2011. A new early Smithian ammonoid fauna from the Salt Range (Pakistan). Swiss Journal of Palaeontology 130, 187-201. DOI 10.1007/s13358-011-0018-3

Brühwiler, T., Bucher, H., Ware, D., Hermann, E., Hochuli, P. A., Roohi, G., Rehman, K. \& Yaseen, A. 2012. Smithian (Early Triassic) ammonoids from the Salt Range, Pakistan. Special Papers in Palaeontology 88, 1-114.

Brühwiler, T., Goudemand, N., Galfetti, T., Bucher, H., Baud, A., Ware, D., Hermann, E., Hochuli, P.A. \& Martini, R. 2009. The Lower Triassic sedimentary and carbon isotope records from Tulong (South Tibet) and their significance for Tethyan palaeoceanography. Sedimentary Geology 222, 314-332. DOI 10.1016/j.sedgeo.2009.10.003
Cossmann, M. 1895b. Essais de Paléoconchologie Comparée. Première Livraison. 161 pp. M. Cossmann, Comptoir Géologique, Paris.

Cossmann, M. 1909. Essais de Paléoconchologie Comparée. Huitième Livraison. 248 pp. M. Cossmann, F.R. de Rudeval, Paris.

Cox, L.R. 1960. Gastropoda. General characteristics of Gastropoda, 84-169. In Knight, J.B., Cox, L.R., KeEN, A.M. , Smith, A.G., Batten, R.L., Yochelson, E.L., Ludbrook, N.H., Robertson, R., Yonge, C.M. \& Moore, R.C. (eds) Treatise on Invertebrate Paleontology. Part I. Mollusca 1. Geological Society of America, Inc. \& University of Kansas Press, Lawrence.

CUVIER, G. 1797. Tableau élémentaire de l'histoire naturelle des animaux. 710 pp. Baudoin, Paris.

DieTZ, E. 1911. Ein Beitrag zur Kenntnis der deutschen Zechsteinschnecken. Jahrbuch der Königlich Preussischen geologischen Landesanstalt zu Berlin 30, 444-506.

Garzanti, E., Nicora, A. \& Rettori, R. 1998. Permo-Triassic boundary and Lower to Middle Triassic in South Tibet. Journal of Asian Earth Sciences 16, 143-157.

DOI 10.1016/S0743-9547(98)00007-5

Griesbach, C.L. 1891. Geology of Central Himalayas. Memoirs of the Geological Survey of India 23, 1-232.

Guex, J. 1978. Le Trias inférieur des Salt Ranges (Pakistan): Problémes biochronologiques. Eclogae Geologicae Helvetiae $71,105-141$.

HaLl, J. 1858. Palaeontology of Iowa. Report of the Geological Survey of the state of Iowa 1(2), 473-724.

HARPER, D.A.T. 1981. The use - and misuse - of Ianthinopsis Meek and Worthen, 1866 (Mollusca, Gastropoda). Journal of Paleontology 55, 180-185.

Hermann, E., Hochuli, P. A., Méhay, S., Bucher, H., Brühwiler, T., Ware, D., Hautmann, M., Roohi, G., uR-Rehman, K. \& YASEEN, A. 2011. Organic matter and palaeoenvironmental signals during the Early Triassic biotic recovery: The Salt Range and Surghar Range records. Sedimentary Geology 234, 19-41. DOI 10.1016/j.sedgeo.2010.11.003

Hollingworth, N. \& Pettigrew, T. 1988. Zechstein reef fossils and their palaeoecology. Palaeontological Association Field Guides to Fossils 3, 1-75.

KaIM, A. 2009. Gastropods, 141-156. In Shigeta, Y., ZaKharov, Y.D., Maeda, H. \& Popov, A.M. (eds) The Lower Triassic System in the Abrek Bay area, South Primorye, Russia. National Museum of Nature and Science Monographs 38.

Kaim, A. \& NüTZEL, A. 2011. Dead bellerophontids walking The short Mesozoic history of the Bellerophontoidea (Gastropoda). Palaeogeography, Palaeoclimatology, Palaeoecology 308, 190-199. DOI 10.1016/j.palaeo.2010.04.008

Kaim, A., NütZel, A., Bucher, H., BrÜhwiler, T. \& Goudemand, N. 2010. Early Triassic (Late Griesbachian) gastropods from South China (Shanggan, Guangxi). Swiss Journal of Geosciences 103, 121-128. DOI 10.1007/s00015-010-0005-5

KitTL, E. 1894. Die Gastropoden der Schichten von St. Cassian der südalpinen Trias. 3. Theil. Annalen des kaiserlich-königlichen Naturhistorischen Hofmuseums 9, 143-275.

KNIGHT, J.B. 1931. The gastropods of the St. Louis, Missouri, Pennsylvanian outlier: the Subulitidae. Journal of Paleontology $5,177-229$. 
KnIGHT, J.B. 1941. Palaeozoic Gastropod Genotypes. Geological Society of America, Special Papers 32, 1-510.

KNIGHT, J.B. 1956. New families of Gastropoda. Journal of the Washington Academy of Sciences 46, 41-42.

KoKEN, E. 1896. Die Gastropoden der Trias um Hallstatt. Jahrbuch der Kaiserlich-königlichen Geologischen Reichsanstalt 46, 37-126.

KoninCK, L.G. DE 1881. Faune du calcaire carbonifère de la Belgique, 3e partie, Gastéropodes. Musée Royale d'Historie Naturelle Belgique Annales, Série Paléontologique 6, 1-170.

KonINCK, L.G. DE 1882. Notice sur la famille des Bellerophontidae suivie de la description d'un nouveau genre de cette famille. Annales de la Société Géologique de Belgique 9, 72-90.

Kummel, B. \& Teichert, C. 1970. Stratigraphy and paleontology of the Permian-Triassic boundary beds, Salt Range and TransIndus Ranges, West Pakistan. Stratigraphic Boundary Problems: Permian and Triassic of West Pakistan. University of Kansas Department of Geology Special Publication 4, 1-110.

M'Coy, F. 1844. A synopsis of the characters of the Carboniferous limestone fossils of Ireland. 274 pp. University Press, Dublin. DOI 10.5962/bhl.title.11559

McCoy, F. 1852. A synopsis of the classification of the of the British Palaeozoic rocks [By the Rev. Adam Sedgwick] with a systematic description of the British Palaeozoic fossils in the Geological Museum of the University of Cambridge [by Frederick McCoy] with figures of the new and imperfectly known species. 661 pp. Parker \& Son, London.

Murata, M. 1981. Permian and Triassic Gastropoda from Guryul Ravine. Palaeontologia Indica 46, 125-133.

MüNSTER, G.G. Zu 1841. Beiträge zur Geognosie und PetrefactenKunde des Südöstlichen Tirol's vorzüglich der Schichten von St. Cassian. 152 pp. Buchner'schen Buchhandlung, Bayreuth.

NüTZEL, A. 2005. Recovery of gastropods in the Early Triassic. Comptes Rendus Palevol 4, 501-515. DOI 10.1016/j.crpv.2005.02.007

NüTZEL, A., Erwin, D.H. \& MAPES, R.H. 2000. Identity and phylogeny of the Late Paleozoic Subulitoidea (Gastropoda). Journal of Paleontology 74, 575-598. DOI 10.1666/0022-3360(2000)074<0575:IAPOTL >2.0.CO;2

NÜTZEl, A., FrÝdA, J., YANCEY, T.E. \& ANDERSON, J.R. 2007. Larval shells of Late Palaeozoic naticopsid gastropods (Neritopsoidea: Neritimorpha) with a discussion of the early neritimorph evolution. Paläontologische Zeitschrift 81, 213-228.

NütZel, A. \& NakaZaWA, K. 2012. Permian (Capitanian) gastropods from the Akasaka Limestone (Gifu Prefecture, Japan). Journal of Systematic Palaentology 10, 103-169. DOI 10.1080/14772019.2010.549659

NÜTZEL, A. \& PAN HuA-ZHANG 2005. Late Paleozoic evolution of the Caenogastropoda: larval shell morphology and implications for the Permian/Triassic mass extinction event. Journal of Paleontology 79, 1175-1188.

NüTZEl, A. \& SChULBERT, C. 2005. Facies of two important Early Triassic gastropod lagerstätten: implications for diversity patterns in the aftermath of the end-Permian mass extinction. $\mathrm{Fa}$ cies 51, 480-500. DOI 10.1007/s10347-005-0074-5

RAFINESQUE, C.S. 1815. Analyse de nature, ou tableau de l'univers et des corps organismes. 223 pp. L'auteur \& Jean Barravecchia, Palerme.
Romano, C., Goudemand, N., Vennemann, T.W., Ware, D., Schneebeli-Hermann, E., Hochuli, P.A., Brühwiler, T., BrinkmanN, W. \& Bucher, H. 2012. Climatic and biotic upheavals following the end-Permian mass extinction. Nature Geoscience 6, 57-60. DOI 10.1038/ngeo1667

SCHINDEWOLF, O.H. 1953. Über die Faunenwende vom Paläozoikum zum Mesozoikum. Zeitschrift der Deutschen Geologischen Gesellschaft 105, 153-183.

Schмid, M. 1928. Die Lebewelt unserer Trias. 461 pp. Rau, Öhringen.

Schмid, M. 1938. Die Lebewelt unserer Trias. Nachtrag. 144 pp. Rau, Öhringen.

Simroth, H. 1906. Versuch einer neuen Deutung der Bellerophontiden. Sitzungsberichte der naturforschenden Gesellschaft zu Leipzig 1905, 3-8.

Sowerby, J. DE C. 1827. No. XCVII of the mineral conchology of Great Britain; or colored figures and descriptions of those remains of testaceous animals or shells, which have been preserved at various times and depths in the Earth. The mineral conchology of Great Britain 6(47), 87-156.

Spath, L.F. 1930. The Eotriassic invertebrate fauna of East Greenland. Meddelelser om Grønland 83, 1-90.

STILLER, F. 2001. Fossilvergesellschaftungen, Paläoökologie und paläosynökologische Entwicklung im Oberen Anisium (Mittlere Trias) von Qingyan, insbesondere Bangtoupo, Provinz Guizhou, Südwestchina. Münstersche Forschungen zur Geologie und Paläontologie 92, 1-523.

Tichy, G. 1980. Über die Erhaltung von Farben und Farbmustern an triassischen Gastropoden-Gehäusen. Verhandlungen der Geologischen Bundesanstalt A 1980(2), 175-217.

WaAgen, W. 1880. Salt-Range fossils. Vol. I, Productus-limestone fossils. Part II, Pisces-Cephalopoda: supplement. Gasteropoda. Palaeontologia Indica 13(1), 73-183.

WaAgen, W. 1895. Salt-Range fossils. Vol. II. Fossils from the Ceratite Formation. Part I. Pisces-Ammonoidea. Palaeontologia Indica 13(2), 1-323.

Wasmer, M., Hautmann, M., Hermann, E., Ware, D., Roohi, G., uR-Rehman, K., Yaseen, A. \& Bucher, H. 2012. Olenekian (Early Triassic) bivalves from the Salt Range and Surghar Range, Pakistan. Palaeontology 55, 1043-1073. DOI 10.1111/j.1475-4983.2012.01176.x

Wenz, W. 1938. Gastropoda. Teil 2: Prosobranchia, 241-480. In Schindewolf, O.H. (ed.) Handbuch der Paläozoologie, Band 6. Verlag von Gebrüder Borntraeger, Berlin.

WheELEy, J.R. \& TwitchETT, R.J. 2005. Palaeoecological significance of a new Griesbachian (Early Triassic) gastropod assemblage from Oman. Lethaia 38, 37-45. DOI 10.1080/0024116051003150

Yochelson, E.L. \& Hongfu, Y. 1985. Redescription of Bellerophon asiaticus Wirth (early Triassic: Gastropoda) from China, and a survey of Triassic Bellerophontacea. Journal of Paleontology 59, 1305-1319.

Yochelson, E.L. \& Saunders, B.W. 1967. A bibliographic index of North American Late Paleozoic Hyolitha, Amphineura, Scaphopoda, and Gastropoda. Geological Survey Bulletin 1210, 1-271.

YÜ, W. 1975. The Gastropod fossils from the Qomolangma Feng Region. 214 pp. Science Press, Peking. [in Chinese] 